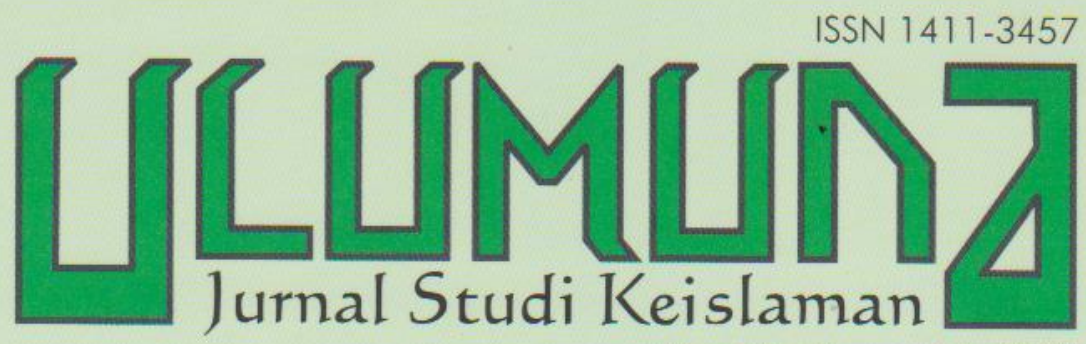

Volume XI• Nomor 1 • Juni 2007

TIELAAM - ISTORIS

PERKENBANEAN OR ENTAUSME ABAD XV-XX

Rendra khaldun

MENXBAK

KENGRASANSIMBOWK ORENTALISE

Iswaknudi

ORIENTALISME

DAN 6PAY DIALOCANTARPERADABAN

Nitivillah

MENCARIE ORENTALISME: MERETAS INAN KE ARAH

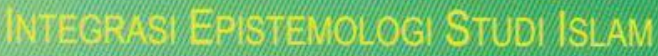
Afrizal

ORENTASM L LBERALSMEISLAM, DAN PENGENBANGAN STUD SLAMDIAIN Alwwan Fanani

MENGURA RAOKALSE ACAMA DU NDONESIA

PASCA OROE BARU Albater Merket Rout 


\section{PEDOMAN TRANSLITERASI}

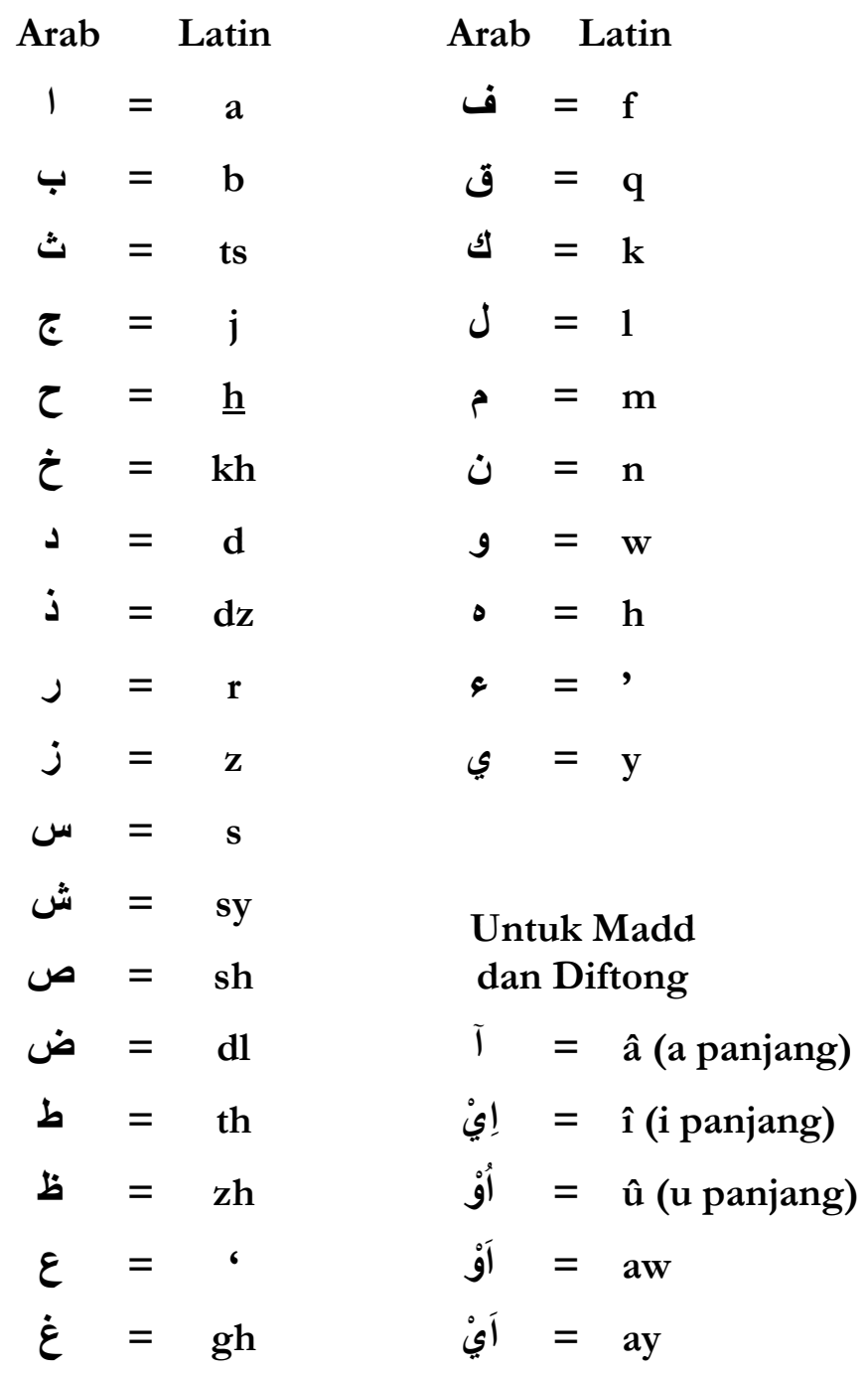


TRANSLITERASI

ANTARAN

UTAMA

Rendra Khaldun

Iswahyudi

Mutiullah

Afrizal

Ahwan Fanani

LEPAS

Miftahul Huda

Ismail Thoib

Abdul Mukti Ro'uf

Ahmad Fathan Aniq

Put

Telaah Historis Perkembangan

Orientalisme Abad XVI-XX • 1-26

Menyibak Kekerasan Simbolik

Orientalisme • 27-52

Orientalisme dan Upaya

Dialog Antarperadaban • 53-72

Mengarifi Orientalisme:

Meretas Jalan ke Arah Integrasi

Epistemologi Studi Islam • 73-92

Orientalisme, Liberalisme Islam, dan Pengembangan Studi Islam

di IAIN • 93-120

Membaca Teks Hadis: Antara Makna

Literal dan Pesan Utama • 121-140

Menggagas Reformasi Pendidikan Islam:

Telaah Filosofis Paradigmatik • 141-156

Mengurai Radikalisme Agama di Indonesia Pasca Orde Baru • 157-176

Rejection of Perda Zakat in East Lombok:

Public Criticism on Public Policy $\bullet 177$ -

198

Ulas BuKu

Fachrizal Halim Self-Criticism to Arab and Muslim

Intellectuals • 199-212

INDEKS 


\title{
MENGARIFI ORIENTALISME: MERETAS JALAN KE ARAH INTEGRASI EPISTEMOLOGI STUDI ISLAM
}

\author{
Afrizal $^{*}$
}

\begin{abstract}
Islamic studies taken by orientalists are often suspected as having bidden agenda. Main indicator of such agenda, according to Edward $W$. Said, is their biased works on Islam. Regardless to its negative side, honestly to say, orientalism has contributed important aspects in Islamic studies in terms of establishing approaches and methodologies, and creating new fields as branches of Islamic studies. Besides, they do give significant role in preservation and maintenance of Muslim intellectual heritage (turâts) such as manuscripts. In the context of Islamic studies in LAIN, the raise of attention to orientalism studies will gradually balance the hegemony of its textual tradition based on Arabs and Persian bayânî and irfânî epistemologies with Western sciences that are compatible with burhânî epistemology. The balance hopefully would be a kind of Islamic studies that more historical and inclusive in nature, analyzing any problem not only from religious but scientific perspective as well.
\end{abstract}

Keywords Oriental, al-Turâts, Orientalisme, Oksidentalisme, Orientalis, Hegemoni.

DUNIA Timur (oriental) dalam pengertian luas memang tidak secara eksplisit menyangkut dunia muslim. Bahkan dalam penggunaannya, oriental mengacu pada tiga wilayah besar geografis dan kebudayaan dunia Timur. Pertama, wilayah

*Penulis adalah alumnus Program Magister Pascasarjana UIN Sunan Kalijaga Yogyakarta. e-mail: africoe@yahoo.com 
geografis dan kebudayaan Asia Timur (sinized) yang mencakup China, Jepang, dan Korea. Kedua, wilayah geografis dan kebudayaan India (indianized) yang mencakup India, Pakistan, Bangladesh, dan Srilangka. Ketiga, wilayah geografis dan kebudayaan muslim. Baik dalam kajian Edward W. Said dan sarjana muslim lainnya, orientalisme mengacu kepada pengertian ketiga wilayah tersebut dan dunia muslim. ${ }^{1}$

Secara politis, penelitian, kajian, dan pandangan Barat tentang dunia muslim, secara eksplisit bertujuan untuk mewujudkan dominasi dan hegemoni politik. Karenanya, orientalisme diasumsikan mengabdi kepada kepentingan politik kolonialisme Eropa untuk menguasai wilayah-wilayah muslim (Dâr al-Islâm).

Kolonialisme Eropa tak bisa lain berkaitan dengan kepentingan ekonomi sekaligus juga kepentingan agama. Semua kepentingan dan motif orientalis yang "dibungkus" dengan wacana ilmiah dan akademis, sebagaimana dalam pandangan Said, secara implisit cenderung bersifat rasis. Hal ini tercermin dari slogan Eropa (Barat umumnya) "mission civilatric", atau "misi pembudayaan" terhadap dunia Timur yang kerap diartikan dunia yang terbelakang, untuk tidak menyebut primitif.

Anehnya, para orientalis Barat kontemporer juga mengakui adanya motif-motif tersembunyi pada teman-teman mereka sepanjang abad. Maxime Radinson, seorang orientalis Perancis, dalam bukunya yang berjudul Mohammad, mengakui adanya motif-motif tertentu para penulis Barat, meskipun ia dengan cerdik mengecualikan dirinya dari kategori ini. Radinson secara terbuka mencela al-Qur'an sebagai kitab suci, meskipun ia mengatakan bahwa dirinya menghormati keyakinan orang Islam tersebut, serta menambahkan: "tetapi saya tidaklah termasuk kategori itu, dan saya tidak ingin terjebak seperti apa yang telah

${ }^{1}$ Maxime Rodinson, Muhammad (New York: Random House, Inc., 2002), 351. 
dilakukan orientalis, pada ungkapan-ungkapan yang samar untuk menyembunyikan kelicikan saya." 2

Sekarang jika dilihat kritik keras Said yang sedikit menghunjam dari beberapa tulisannya, tentu sangat mengguncangkan orientalis. Perdebatan panas yang terjadi pertama-tama tentu saja menyangkut motif-motif di balik orientalisme itu. Hasilnya menurut Said tentang kajian mereka, tidak bisa lain kecuali tidak objektif dan mengandung bias atau "distortion". Karena itu, kajian-kajian yang objektif, tidak mengandung bias dan distortion, hanya bisa dihasilkan from within, yaitu dilakukan sarjana, peneliti, atau kalangan yang berasal dari dalam tradisi sendiri. Hal ini karena mereka lebih bisa memahami serta mengapresiasi warisan dan tradisi mereka, ketimbang orang di luar tradisi tersebut. Sebab, hasil kajian mereka, baik dalam bentuk penelitian secara langsung maupun melalui bacaan ilmiah, di mana hal tersebut bisa lebih objektif dan "fair" dibandingkan dengan kajian dan penelitian orientalis, menurut Said. Hal tersebut juga disebabkan orientalis tidak memahami kondisi yang sebenarnya tentang dunia Timur itu sendiri. Benarkah beberapa statemen di atas yang lebih melihat perbedaan latar belakang sosial kultural seseorang, serta di mana mereka dilahirkan, ketimbang objektivitas ilmu pengetahuan yang melekat pada mereka? Inilah sepenggal tulisan yang mencoba membedah persoalan tersebut.

Argumen terakhir di atas tidaklah sepenuhnya benar, di mana memang betul sarjana atau peneliti from within lebih mungkin memiliki simpati dan apresiasi terhadap subjek kajiannya, tetapi hal ini tidak menjadi jaminan bahwa mereka akan menghasilkan kajian yang objektif dan tidak bias. Yang sering terjadi justru latar belakang ini menjadi handicap (semacam halangan) bagi banyak di antara mereka untuk menghasilkan kajian-kajian yang objektif. Sebab, banyak di antara sarjana dan peneliti from within,

${ }^{2}$ Ibid., 351. 
justru tergelincir menjadi tidak objektif karena tidak mampu mengambil jarak atau tidak terlibat terhadap subjek kajian yang merupakan tradisi sendiri. Hasilnya, mereka tidak mau bersikap analitis dan kritis terhadap kajian dimaksud. Jika tidak bias, sedikitnya hasil kajian mereka bisa lebih merupakan apologi dan pembelaan belaka yang dibungkus dengan teori-teori ilmiah. Sementara beberapa orientalis telah jauh melangkah dengan mencoba melakukan penelitian, baik terhadap tradisi sendiri maupun tradisi luar mereka dengan menanggalkan apologi dan sentra tradisi secara subjektif.

\section{Melacak Realitas}

Harus diakui bahwa dunia sekarang adalah dunia postmodernisme atau dunia kontemporer, yang di dalamnya penuh dengan nilai multikultural dan multireligius yang disertai dengan ketatnya persaingan globalisasi yang begitu cepat berubah. Andaikan masih ada sivitas akademika, khususnya IAIN yang berpikir dan berpandangan era klasik-single entity atau isolated entity, tentu mereka akan ketinggalan kereta yang dikarenakan kesalahan mereka sendiri.

Sebab dari beberapa asumsi yang muncul belakangan ini di perguruan tinggi sekelas IAIN tentang arah kajian orientalisme, penulis ingin menegaskan bahwa perubahan bentuk dan arah kajian orientalisme yang semula berkiblat pada dunia Arab, kemudian berpaling pada dunia Barat adalah babak awal untuk mengantarkan (IAIN) ke gerbang yang amat kompleks. Artinya perubahan ini secara ilmu pengetahuan, setidaknya perlu mendapatkan perhatian penuh oleh semua pihak. Sebab, tanpa perubahan, IAIN akan tetap "mandul" dengan hegemoni teksnya. Sedikit agak inklusif, di mana penulis berasumsi dengan perubahan kiblat dari Arab (Muslim) pada Barat, IAIN akan mencatat sejarahnya sendiri dalam pergulatan kompetisi dunia yang semakin canggih, khususnya kompetisi dalam bidang 
penelitian dan pendidikan ilmu orientalisme serta epistemologi Islam.

Secara positif dapat dimaknai bahwa dengan banyaknya kajian orientalisme di IAIN yang berkiblat pada dunia Barat, maka berarti secara perlahan IAIN akan bisa menyeimbangkan hegemoni budaya teksnya yang diwariskan oleh dunia Arab lewat -meminjam istilah 'Âbid al-Jâbirî- epistemologi bayânî dan epistemologi irfânî dari Persia. Artinya lewat kajian orientalisme Barat, IAIN sebagai perguruan tinggi Islam Indonesia tidak lagi dan hanya bersentuhan dengan ilmu-ilmu orientalis dalam kajian Timur Islam yang normatif, tetapi sudah bersentuhan dengan ilmu orientalis Barat yang secara sederhana bermakna historis dan inklusif. Hal tersebut di samping mempermudah pemahaman sivitas akademika terhadap dunia mereka sendiri, juga sebagai pandangan objektif dalam melihat setiap permasalahan dengan kaca mata ilmiah. Hal tersebut juga sebagai modal mempertemukan semua unsur dalam bentuk interconnected entities. Artinya dengan banyak kajian orientalis yang berkiblat pada Barat tersebut, bagi sivitas akademika IAIN akan menjadi being process tersendiri bagi pengembangan ilmu pengetahuan dalam ranah ilmu yang dikaji secara internal, ketimbang melulu mencontek dan menerima secara taklid dan bersikap pasrah diri.

\section{Menuju Studi Islam yang Mencerahkan}

Terjadinya perubahan kiblat pada kajian-kajian yang dilakukan orientalis, pada dasarnya hal tersebut bukanlah "pemurtadan", "pengkafiran" atau "pembodohan" sebagaimana yang banyak dilansir sarjana belakangan ini. Harus diakui dan disadari bahwa orientalisme tidak hanya memiliki sisi negatif yang "menjengkelkan", sebagaimana dikritik oleh Said dan sarjana muslim lainnya. Jika dikaji secara objektif, kajian orientalisme telah memberikan banyak sumbangan kepada kajian Islam dan dunia muslim pada umumnya, yaitu; pertama, 
orientalisme memberikan kontribusi besar dalam pendekatan (approaches) dan metodologi (metholodogy) dalam kajian Islam dan dunia muslim. Kedua, orientalisme juga memberikan kontribusi signifikan dalam penyelamatan (preservation) dan pemeliharaan (maintenance) warisan (al-turâts) intelektual muslim berupa naskahnaskah penting (manuscripts). Bahkan sarjana Barat atau orientalis tersebut berperan penting dalam memulihkan kembali warisan intelektual tersebut, dengan melakukan usaha-usaha filologis. Ketiga, para sarjana Barat (orientalis) juga telah membuka bidangbidang baru dalam kajian tentang Islam dan dunia muslim.

Lebih dari itu, dalam kritikan Said terdapat dorongan bagi kalangan sarjana Muslim untuk mengembangkan sebuah ilmu baru yang disebut dengan oksidentalisme. Dengan ilmu ini, mereka bertujuan menggali dan mengungkapkan dunia Barat berdasarkan perkembangan berbagai aspek kehidupan Barat itu sendiri yang bisa dipandang sebagai counter knowledge bagi orientalisme.

Tetapi harus diakui, sejak gagasan tentang oksidentalisme dalam bahasa Arab disebut "al-istighrâb", yang mulai menemukan momentumnya menjelang akhir 1980-an, hemat penulis belum banyak kemajuan signifikan yang berhasil dicapai. Artinya kajian dan wacana oksidentalisme yang berkembang lebih berpusat dan terfokus pada aspek pemikiran dan filsafat Barat, sebagaimana terlihat dalam karya $\underline{H}$ assan $\underline{\text { Hanafî }}$ pada catatan pengantar ilmu oksidentalisme yang merupakan sumbangan penting ke arah oksidentalisme. ${ }^{3}$

Jika oksidentalisme merupakan sebuah wacana akademis dan ilmiah pengimbang orientalisme (bukan sebagai lawannya seperti dalam pandangan Kamarudin Hidayat), maka cakupan kajiannya sudah sepatutnya tidak terbatas hanya pada bidang filsafat dan pemikiran. Seperti juga orientalisme, wacana oksidentalisme

${ }^{3}$ Untuk lebih lengkap tentang oksidentalisme, lihat Hassan Hanafi, Oksidentalisme: Sikap Kita terhadap Tradisi Barat, ter. M. Najib Buchori (Jakarta: Paramadina, 2000). 
mestilah mencakup kajian dalam bidang antropologi, etnologi, sosiologi, politik, ekonomi, sejarah, dan sebagainya. Tanpa cakupan "multidiscipliners" seperti itu, oksidentalisme akan bisa gagal menjadi wacana akademis dan ilmiah untuk memahami dunia Barat, seperti yang dilakukan orientalis.

Dalam hal ini oksidentalisme sudah seharusnya mengkaji dan menganalisis segala fenomena yang diinginkan dengan menggunakan metode yang setidak-tidaknya sama dengan yang dilakukan dalam kajian orientalisme. Kalau tidak bisa lebih, sekurang-kurangnya sama, agar apa yang dimaksud bisa tercapai dengan hasil yang memuaskan dan objektif.

Secara sederhana oksidentalisme dapat didefinisikan sebagai paham, pengetahuan, atau pandangan dunia timur tentang Eropa, Amerika, atau Barat pada umumnya. Atau lebih khususnya, oksidentalisme berarti pandangan dan pengetahuan dunia Islam tentang dunia Barat. ${ }^{4}$

Istilah oksidentalisme sebagai istilah maupun wacana akademis baru muncul paling "banter" sejak awal dasawarsa 1980-an. Kemunculannya berkaitan erat dengan penerbitan buku yang berjudul "Orientalism" karya Edward W. Said, ${ }^{5}$ di mana karya ini segera menyulut kehebohan dan kontroversi di lingkungan dunia akademis Barat yang biasa disebut sebagai kaum orientalis. Lebih lanjut, sendi-sendi orientalisme bisa goyah karena argumen-argumen yang dikemukakan Said. Inilah output yang harus diambil oleh sivitas akademika IAIN dalam meneliti semua aspek yang menyangkut ilmu pengetahuan, budaya, politik, ekonomi, dan semisalnya. Bukan bergegas melakukan truth claim melalui pernyataan kafir dan murtad, karena di samping klaim semacam ini cukup memalukan, juga

${ }^{4}$ Lihat Komaruddin Hidayat, "Oksidentalisme: Dekonstruksi terhadap Barat", dalam ibid., xiii-xx.

${ }^{5}$ Lihat Edwar W. Said, Orientalism: Western Conception of the Orient (London: Penguin, 1991). 
berarti melakukan pembodohan terhadap generasi muda Indonesia, khususnya sivitas akademika IAIN.

Sebagai ilustrasi terhadap analisis orientalisme tersebut, sebut saja rasionalisme dan empirisme sebagai epistemologi dominan yang diusung dunia modern belakangan ini banyak menuai kecaman. Kecaman itu muncul disebabkan karena dunia modern diasumsikan gagal membebaskan manusia dari kungkungan luar dirinya. Abad modern yang membawa visi dan misi awal membebaskan manusia dari determinasi alam dan mitologi serta mengubah peran objek menjadi subjek, ternyata justru menjerumuskan manusia dalam kubangan hegemoni lain. Manusia terjebak-meminjam bahasa Karl Marx-dalam "fetisisme komoditi" (rasa cinta berlebihan terhadap komoditi dan hanya terpuaskan oleh komoditi itu).

Pada saat kritik melimpah dan bertubi-tubi itulah Juergen Habermas muncul sebagai penerus sekaligus pembaru ide Frankfurt Schule, dalam arti menerima kritik itu sambil meluruskan kesalahan dunia modern. Cacat-cacat modernisasi dalam bentuk totalitarianisme, hilangnya makna, dan animie, menurutnya disebabkan karena pemiskinan rasionalisme Barat pada paradigma filsafat kesadaran tersebut. Cacat-cacat ini bisa diatasi dengan melanjutkan proyek modernitas dalam wawasan dan kawasan rasio komunikatif. ${ }^{6}$ Komunikasi inklusif dan mengedepankan penelitian secara ilmiah dan objektif adalah bentuk awal menerobos kebobrokan modernisme tersebut.

Secara sederhana, hal inilah yang belum dilakukan oleh para sarjana muslim atau peneliti Islam, khususnya IAIN untuk mengelaborasi dan mengintimasi setiap permasalahan yang muncul kepermukaan, termasuk kajian orientalisme yang telah mengalami pergeseran arah kiblat kajian keislaman tersebut, bahkan sering dijadikan kambing hitam bagi mereka yang tidak

${ }^{6}$ F. Budi Hardiman, Menuju Masyarakat Komunikatif (Yogyakarta: Kanisius, 1993), xiv. 
mengerti permasalahannya secara saksama. Yang terjadi malah adanya "kebablasan" truth claim.

Semenjak kebudayaan yang berkembang berada di bawah kajian orientalis yang berafiliasi pada Arab, IAIN selalu diidentikkan dan didominasi oleh kebudayaan teks. Semacam kebudayaan yang dikonstruksi oleh sebuah pandangan dunia yang berpusat pada otoritas Tuhan melalui teks kitab suci. Maka yang terjadi adalah terkesan "membela teks". ${ }^{7}$ Bagian inilah yang disebut al-Jâbirî sebagai akibat implikasi nalar bayânî, salah satu nalar yang menjadikan ilmu bahasa Arab sebagai tema sentralnya. Pada konteks ini, bahasa bukan sekedar sebagai alat komunikasi atau sarana berpikir melainkan lebih dari itu, yaitu suatu wadah yang membatasi ruang lingkup pemikiran. Inilah yang dimaksud dengan hegemoni epistemologi yang berkembang di IAIN_yang diasumsikan memiliki "status sosial" dengan kiblat menghadap Barat. Pada dasarnya hegemoni tersebut dapat dilepaskan dengan mengembangkan budaya/nalar burhânî guna mempertajam pondasi epistemologi dan khazanah baru IAIN, terkhusus dalam kajian orientalisme. Hal ini berarti bahwa dalam melakukan kajian orientaliasme yang berkiblat pada Barat, sudah semestinya lembaga IAIN (khususnya sivitas akademikanya) menggunakan nalar burhân̂̂ guna menghindari truth claim dan menemukan arti sesungguhnya dari maksud kajian orientalis.

Di samping nalar bayân̂̀ yang berkembang dan menghegemoni sivitas akademika IAIN, oleh orientalis juga dikembangkan penggunaan nalar irfânî, semacam nalar yang sama sekali berbeda vis a vis dengan nalar bayânî. Jika nalar bayânî lebih memfokuskan pada zahir teks, maka irfânî menekankan pada bathinnya, sebuah pengetahuan yang diperoleh melalui kasyf atau ilhâm dan hal-hal yang bersifat esoterik. Jika nalar

${ }^{7}$ Muhammad 'Abid Al-Jâbirî, Takwîn al-Aql al-'Arabî (Beirut: Markâz Dirâsah al-Wihdah al-'Arabiyah, 1989), 76. 
bayânî merupakan nalar murni sekaligus kekhasan dunia Islam, maka nalar irfânî merupakan adopsian dari tradisi praIslam semisal Neo-Platoniasme.

Dari perspektif di atas dapat digambarkan bahwa di satu sisi kebudayaan adalah sistem nilai, karena itu, dengan sendirinya akan mempengaruhi individu dan sebaliknya. Di sisi lain kajian orientalisme yang sudah mengakar dan "mendarah daging" juga merupakan suatu sistem nilai yang secara tidak langsung juga mempengaruhi individu. Proses interaksi sistem nilai budaya kajian orientalisme antara konsep Timur dan konsep Barat dalam mempengaruhi individu tanpa dapat dihindari akan menimbulkan gesekan atau tarik menarik satu sama lainnya. Hal ini akan terlihat jelas bila keduanya sudah menyentuh pada level sosio-kultural dan politik. Hal ini terlihat dalam bagan di bawah ini:

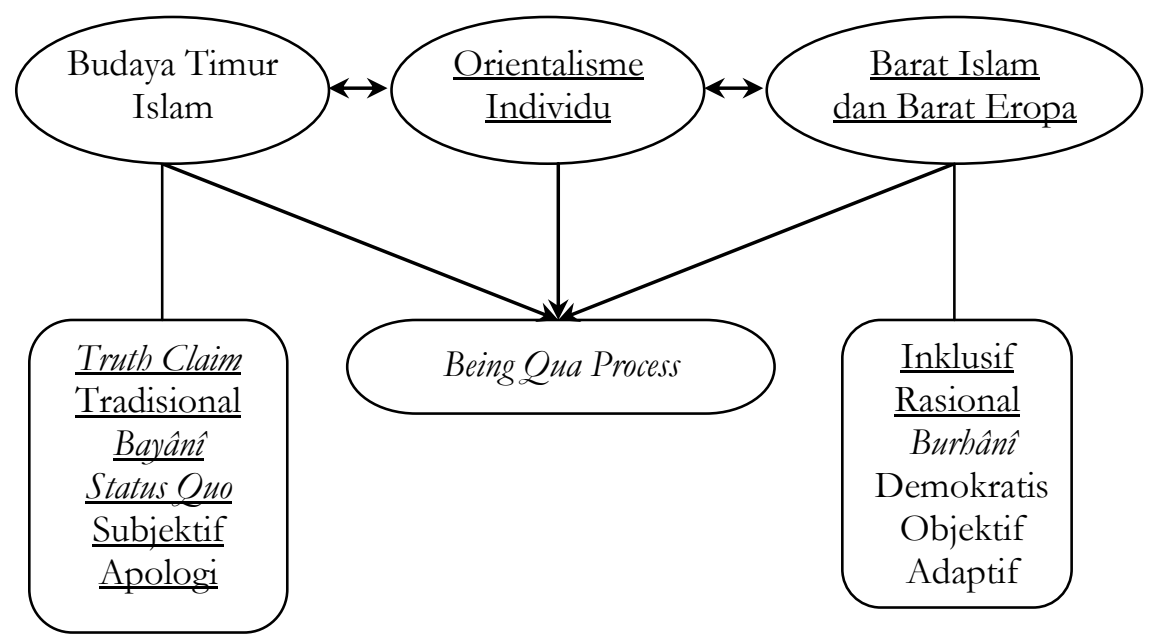

Dari bagan tersebut, proses take and give dalam kebudayaan sangat erat kaitannya dengan sejauh mana manusia yang berproses dapat mengendalikannya dengan baik dan saling terbuka guna menjadikan arah penelitian dan kajian orientalisme sebagai pusat budaya yang bersahabat, akomodatif, dan kreatif. 
Secara kasat mata, orientalisme memang bertentangan dengan budaya ketimuran.

Namun dalam kenyataannya tidaklah demikian, karena pada esensinya kebudayaan didasarkan pada ajaran bahwa "alam" harus dijadikan guru. Artinya, dalam melakukan sebuah penelitian dan kajian kebudayaan terdapat muatan nilai yang mengandung firman Tuhan, bahwa alam mengungkapkan beberapa rahasia-Nya kepada siapa saja yang mampu menerjemahkan secara tepat. Inilah output inklusif yang harus diluncurkan oleh sivitas akademika IAIN sebagai perguruan tinggi Islam Indonesia dalam mempertajam paradigma berpikir ke depan. Hal ini mutlak mendapat perhatian "ekstra" dari semua pihak, terlebih dari para "decision maker" yang menghendaki adanya perubahan kualitas lulusan IAIN.

Mengapa dikatakan demikian? Dalam rangka menjawab pertanyaan mendasar ini, hemat penulis perlu dicermati konsep al-Jâbirî tentang realitas keterputusan epistemologi pemikiran di dunia Islam, sejak zaman pertengahan hingga kini. Peta peradaban atau pemikiran Islam secara geografis terbagi menjadi dua wilayah. Pertama adalah wilayah Timur yang meliputi Persia, Mesir, Irak, Syiria, dan Khurasan dengan tokoh-tokohnya yang muncul adalah Ibnu Sinâ, al-Farâbî dan al-Ghazâlî. Kedua adalah wilayah Barat yang meliputi Maroko dan Andalusia (Spanyol) dengan tokohnya yang terkenal Ibnu Rusyd, Ibnu Hazm, dan Ibnu Khaldûn. Dua wilayah ini bagi al-Jâbirî telah mengalami sebuah al-qath'iyyah al-istimulîjia (keterputusan epistemologis). ${ }^{8}$ Epistemologi bayânî dan irfânî di Timur dan epistemologi burhânî di Barat.

Kebudayaan Timur, akibat dua epistemologi di atas, mengalami kevakuman dan hanya mengulang-ulang, tidak produktif, dan selalu konsumtif. Terlebih nalar irfân $̂$ yang hanya

${ }^{8}$ Muhnammad 'Âbid al-Jâbirî, Bunyatu al-'Aql al-'Arabî (Beirut: Markâz Dirâsah al-Wihdah al-Arabiyah, 1990), 275. 
mengurusi wilayah personal serta acuh akan persoalan sosial. Hal ini kontras dengan wilayah Barat, di mana perkembangan ilmu sangat maju, filsafat berkembang pesat, dan produktivitas selalu muncul. Hemat penulis inilah persoalan fundamental yang harus diperhatikan oleh pejabat penting IAIN. Hal ini setidaknya dilakukan dengan cara memperkenalkan kepada fakultas-fakultas yang selama ini dianggap tidak bersentuhan dengan kajian kebudayaan Barat Islam sehingga tidak hanya mengkonsumsi pemikiran al-Ghazâlî secara literal dan eksklusif.

\section{Implikasi terhadap Kajian Keilmuan IAIN}

Kembali pada persoalan epistemologi, di mana jika Habermas menawarkan rasio komunikatif secara sejajar antarsubjek dengan tanpa dominasi dari yang lain, maka John Rawls dalam bukunya $A$ Theory of Justice mengusulkan pentingnya the original position untuk menciptakan keadilan. ${ }^{9}$ Singkatnya, seseorang mesti meninggalkan referensi dirinya dalam memutuskan sesuatu terutama dalam men-set up masyarakat.

Dalam hal ini siapa pun yang menjadi pengambil kebijakan (policy maker) ke depan di lingkungan IAIN haruslah bisa men-set up masyarakat kampus secara adil dengan mengutamakan "sumpah" mengutamakan kepentingan umum di atas kepentingan pribadi dan golongan.

Baik Habermas maupun Rawls mengakui adanya standar objektif dalam mengevaluasi cara suatu masyarakat dididik dan dibentuk. Ada moral universal dalam semua waktu dan setiap masyarakat. Jika Habermas menyebutnya ideal speech situation maka John Rawls menamainya dengan original position. Habermas seperti yang diakui sendiri, sedang mempertahankan gagasan bahwa setiap masyarakat dan semua waktu ada dasar universal dari institusi moral. Sementara John Rawls mengaku telah

\footnotetext{
${ }^{9}$ William C. Placher, Unapologetic Theology (Loisville: Westminster/John Knox, 1989), 81.
} 
menemukan titik Archimedes untuk menilai keadilan sistem sosial. ${ }^{10}$

Paling tidak ada dua hal menarik mengutip teori Placher dalam membicarakan Habermas yang sekaligus sebagai refleksi dan kontribusi penulis atas perubahan kiblat kajian orientalis di IAIN secara keseluruhan. Pertama, Habermas ingin mempertahankan nilai-nilai ideal enlightenment sebagai benteng terhadap serangan-serangan neokonservatif kontemporer. Sebab kelompok tersebut sangat gencar muncul pada tahun 80-an, di antara mereka tokohnya adalah Jean Baudrillard, Jean-Francois Lyotard, Arthur Kroker, Marilousuise Kroker, dan David Cook. Mereka menuduh bahwa transformasi historis yang menjadi ciri khas modernisme mutakhir secara progresif telah merongrong dasar-dasar yang paling pokok dari teori kritis dan sumber teori. ${ }^{11}$

Pada saat inilah Habermas menampakkan atau menampilkan dirinya sebagai penjaga dan penyelamat "proyek modernitas". Kedua, dalam membincangkan Habermas, oleh karena usahanya dalam mempertahankan modernitas berdasarkan analisis presupposisi komunikasi, di mana dalam setiap komunikasi pasti selalu membutuhkan pihak lain. Artinya dalam mengemban amanah sebagai policy maker di lingkungan IAIN, maka alternatif terbaik ke depan adalah mengembangkan komunikasi dalam setiap pengambilan keputusan dengan melibatkan seluruh sivitas akademika, tanpa pandang latar belakang status sosial yang sekaligus menghilangkan sifat miss communication antarfakultas yang ada. Dalam konteks menjaga proyek perluasan dan perubahan kajian orientalisme tersebut, idealnya segala sesuatu ditempatkan secara proporsional, baik dalam bentuk mendidik staf administratif, termasuk upaya pengembangan epistemologi inklusif.

${ }^{10}$ Ibid, 75 .

${ }^{11}$ Bryan Turner, Teori-teori Sosiologi Modernitas Postmodernitas, ter. Imam Baehaqi dan Ahmad Baidlowi (Yogyakarta: Pustaka Pelajar, 2000), 149. 
Sebagai contoh dari cara kerja ideal speech situation Habermas dalam the values of classificationitu adalah dengan mengajukan pertanyaan mendasar; ${ }^{12}$ apakah kajian orientalis itu salah? Jika seseorang menjawab "ya" dengan alasan dilarang oleh Tuhan (alasan agama), berarti orang tersebut masih berada pada moralitas tingkat bawah. Tetapi jika menjawab "belum tentu salah" dengan alasan jika tidak ingin disalahkan orang lain, maka jangan terburu-buru menyalahi orang lain atau melakukan truth claim. Dengan logika sederhana, jika tidak ingin disakiti orang lain maka jangan pernah menyakiti orang lain. Tentu jawaban kedua inilah yang mengandung nilai moral tingkat tinggi yang menggunakan prinsip moral universal.

Inilah persoalan output yang dihasilkan lembaga IAIN selama ini, di mana dosen, mahasiswa, dan alumni hanya mengetahui aspek "normativitas" agama, tetapi "kering" dalam memahami aspek historisitas agama sendiri, lebih-lebih historisitas agamaagama lain. Hal yang amat sulit lagi dilerai andaikan terjadi jalin berkelindan antara satu epistemologi dengan epistemologi lain, dalam arti seringnya tidak menggunakan bantuan metodologi yang digunakan oleh ilmu pengetahuan umum yang acapkali berdiri sendiri-sendiri. Dengan perubahan kiblat kajian orientalis di IAIN, maka dengan berangsur-angsur model berpikir apologetik melalui alasan agama secara kaku dalam memandang berbagai persoalan akan segera lenyap dengan menggunakan model interconnected entities.

Sedangkan persoalan justice (keadilan) yang diluncurkan oleh John Rawls, menurutnya agar pembuat aturan masyarakat mampu mencipta keadilan, maka ia harus memiliki sifat yang disebut oleh Placher dengan the veil of ignorance. ${ }^{13}$ Artinya pembuat keadilan tidak mengerti dia akan menjadi apa sehingga keputusan yang diambil steril dari referensi-referensi

12Placher, Unapologetic..., 86.

${ }^{13}$ Ibid. 
kepentingan. Inilah yang disebut Rawls dengan the original position. Dalam konteks ini, para pejabat penting IAIN mesti dapat melepaskan "baju" kepentingan pribadi, kelompok, maupun golongan guna mencapai the will to be together bagi pengembangan kajian orientalisme dan kemajuan IAIN ke depan. Tanpa the will to be together, IAIN akan tetap mandul, yang hanya mampu menyelenggarakan pendidikan formalitas semata dengan mengkonsumsi kajian orientalisme budaya Timur (Arab) yang bercorak fanatisme dan bersikap egoistik. Pada dasarnya persoalan perubahan arah kiblat kajian orientalis di IAIN merupakan persoalan bagaimana setiap orang yang berada di dalamnya terlibat langsung dalam menyelesaikan berbagai permasalahan dan ikut ambil bagian dalam mengembangkannya.

Jika logika inklusif dari pengembangan budaya kajian orientalisme tidak diklaim sebagai pemurtadan dan pengkafiran, maka implikasi dari pola pemikiran tersebut tidak hanya sebatas tingkat individual tapi juga berdampak secara kolektif, baik sewaktu menjadi mahasiswa IAIN_apalagi setelah menyandang gelar sarjana alias telah menjadi alumni IAIN. Secara konkret sudah semestinya para pejabat penting IAIN memikirkan penambahan kurikulum pada semua fakultas yang memberikan kajian orientalisme dan filsafat corak atau model kebudayaan Barat Islam—sekaligus memperkenalkan kebudayaan Barat centrist, yang tidak hanya bersifat formalitas.

Dengan pemberian kajian semacam itu, tentu mahasiswa akan mempelajari dan mengerti model hermeneutika Martin Heidegger dan Gadamer, atau pemikiran filsuf produktif lainnya. Dalam pandangan al-Jâbirî, perbedaan dua kebudayaan itu setidaknya dipengaruhi oleh dua hal. Pertama, di Barat tidak ada hambatan kultural yang mempertentangkan antara konsep akal dan wahyu. Kedua, tidak adanya warisan praIslam (tidak ada struktur kebudayaan yang mapan). Dengan dua alasan ini, kajian orientalisme Barat mempunyai kemerdekaan dalam 
intelektualisme dibandingkan Timur. ${ }^{14}$ Akal dan wahyu sebagai prototype ilmu pengetahuan di lingkungan IAIN selama ini bagaikan "musuh bebuyutan" yang selalu didominasi oleh wahyu. Hal ini disebabkan kebanyakan mahasiswa IAIN berasal dari kalangan pesantren-yang nota bene amat sarat dengan nuansa teksnya-maka dimungkinkan dengan perubahan arah kiblat ini, mahasiswa IAIN nantinya tidak hanya mengerti konsep fiqh kiai, tapi juga memahami hasil penelitian orientalis tentang budaya Islam.

Jika diperhatikan secara historis, di Timur sebenarnya pernah berkembang pemikir seperti al-Kindî, al-Farâbî, dan Ibnu Sinâ, bahkan dari tangan merekalah filsafat Aristoteles dikenal. Hal yang amat disayangkan pada proses perkembangan selanjutnya mereka terpengaruh oleh tradisi hermeneutis berupa paham emanasi. Dalam bahasa al-Jâbirî mereka terperosok dalam aql mustaqîl, yaitu sebuah nalar yang berangkat dari kajian yang sangat menghargai akal tetapi akhirnya mereka skeptis terhadap kemampuan akal. ${ }^{15}$

Sikap skeptis inilah yang harus dicabut oleh sivitas akademika IAIN dengan mengelaborasi lebih dalam setiap kajian yang akan dipaparkan. Sebab dalam pandangan orientalis, filsafat di Timur benar-benar mengalami "sekarat" ketika al-Ghazâlî menyerangnya dengan Kitab Tậâfut al-Falâsifah. Dalam penilaian Philip K. Hitti, magnum opus al-Ghazâlî tersebut sesungguhnya telah menempatkan umat Islam dalam tidur yang panjang. ${ }^{16}$ Walaupun Ibn Rusyd muncul dari Barat Islam sebagai pembela, tetap saja mengalami hambatan oleh nalar bayânî dan 'irfânî yang telah diperbarui oleh al-Ghazâlî. Tampaknya pengaruh alGhazâlî di dunia Timur sulit dapat dihilangkan dalam waktu sekejap. Sekaratnya filsafat di belahan dunia Timur-termasuk

${ }^{14}$ Muhammad Abid Al-Jabiri, Kritik Kontemporer atas Filsafat Arab-Islam, ter. Moch Nur Ikhwan (Yogyakarta: Islamika, 2003), 95-104.

${ }^{15}$ Al-Jâbirî, Bunyah...,159.

16Philip K. Hitti, History of The Arabs (London: MacMillan, 1964), 73. 
Indonesia-khususnya lagi institusi Islam sekaliber IAIN, sesungguhnya berimplikasi pada maraknya sikap pesimistis pada setiap kali terjadi perubahan, termasuk perubahan kiblat kajian orientalisme dari Timur ke Barat. Jika ini tidak direspons secara baik, tentu akan menjadi pecundang tersendiri bagi generasi muda Indonesia dalam melakukan beragam penelitian yang bernuansa Barat, khususnya lagi generasi muda IAIN sebagai ujung tombak pengembangan ilmu pengetahuan.

\section{Catatan Akhir}

Melalui logika kajian orientalisme yang berkiblat pada Baratlah akal mulai dihargai di Timur Islam. Kajian orientalisme Timur menjadi terbelakang disebabkan kurang menghargai dan menggunakan akalnya yang disebabkan tersubordinasi oleh teks. Dunia Barat Islam dan non Islam menjadi maju dan berkembang karena penghargaan mereka yang tinggi terhadap akal. Sementara tradisi murni dunia Timur adalah tradisi bayân̂̀ yang sempat berkembang pesat dan dijadikan sebagai rujukan awal oleh masyarakat yang berimplikasi terhadap berkembangnya sikap fanatisme buta yang selanjutnya berkembang menjadi sikap truth claim, pengkafiran, dan pemurtadan.

Lebih jauh dalam perkembanganya, kajian yang dilakukan sarjana asing (khususnya Barat), seperti bisa diduga, juga sangat diwarnai ideologi orientalisme, setidaknya sampai berakhirnya Perang Dunia II. Sehingga kajian tentang Dunia Timur khususnya tentang Indonesia didominasi para peneliti dan sarjana Eropa, lebih khusus lagi sarjana Belanda, dan dalam batas tertentu juga sarjana Inggris dan Perancis. Pada perkembangan berikutnya barulah muncul sarjana Amerika yang disusul kemudian oleh Australia dan Eropa lainnya pada masa pascaPerang Dunia II. Dalam hal ini para sarjana tersebut menggunakan keahliannya masing-masing dalam mengkaji dan meneliti Dunia Timur, khususnya Dunia Islam, sehingga 
menghasilkan interpretasi yang berbeda tentang dunia Islam, dikarenakan mereka berasal dari tradisi yang berbeda.

Namun akankah umat Islam hanya menjaga jarak dengan para orientalis dan memusuhinya dengan tafsiran yang mereka buat? Dalam hal ini yang terpenting adalah bagaimana umat Islam (termasuk sivitas akademika IAIN) mampu mencontoh dan meniru para orientalis dalam melaksanakan penelitian tentang keadaan sebuah negara dan ajaran agama dikarenakan mereka juga memberikan andil yang besar terhadap pengembangan agama dan ilmu pengetahuan. Sedangkan secara sportif jika ingin mengetahui lebih jauh eksistensi dunia Barat, kajian mendalam idealnya dilakukan dengan menggunakan kaca mata ilmiah. Hal tersebut tentu juga dengan pengembangan ilmu oksidentalisme agar hasilnya nanti bisa objektif dan fair.

Untuk membangun peradaban Islam lewat kajian-kajian orientalis di IAIN, haruslah banyak berkonsentrasi-dalam berbagai tulisan-terhadap dunia Barat Islam dan non-Islam yang telah meletakkan dasar-dasar burbânî. Kebudayaan burhânî adalah kebudayaan yang mengapresiasi akal, pengalaman, dan indra yang dibuktikan dengan banyaknya menghasilkan ilmuilmu natural serta ilmu-ilmu kemanusiaan. Dengan kata lain, kebudayaan ini lebih menjadikan manusia sebagai subjek yang berbeda dengan kebudayaan bayânî yang memposisikan manusia sebagai objek.

Di belahan Barat Islam, kebudayaan burhânî mendapat porsi besar. Sebab dari sinilah dikenal tokoh kritis Ibnu Hazm muncul yang banyak menggunakan metode kritis terhadap basis-basis yurisprudensi ketimbang bersikap konformis terhadap teks. Dari sini pula muncul Ibnu Rusyd dan sosiolog Ibnu Khaldûn serta tokoh penggagas maqâsid al-syarîah, al-Syatîbî. Dari pemikiran mereka pula seringkali teks ditelanjangi untuk ditemukan makna sesungguhnya. Sebuah kebudayaan yang tidak berani dilakukan oleh kebudayaan teks (bayânî), sebagaimana ditaksir orientalis. Artinya untuk memunculkan kembali orang seperti Harun 
Nasution, Mukhti Ali, perubahan kiblat kajian orientalis tersebut-tidak semestinya dijadikan kambing hitam bagi pemurtadan sivitas akademika IAIN — melainkan sebagai wadah penyambung lidah pemikir-pemikir yang muncul dari IAIN itu sendiri.

Utamanya, setiap fakultas yang ada mempunyai kurikulum yang memberikan fokus pada kajian orientalis dan mempelajarinya secara mendalam sebelum terjadi truth claim yang dalam ranah ilmu pengetahuan sebaiknya dihindarkan. Selain itu sebagai institusi pendidikan agama tinggi, semestinya IAIN mengembangkan budaya komunikasi, guna melenyapkan kebiasaan misscommunication antarsesama civitas academica, sebagaimana yang terjadi selama ini. Serta bersikap adil setiap akan mengambil keputusan dengan menanggalkan referensi diri, kelompok, dan golongan guna mencapai the will to be together dalam pengembangan IAIN ke depan.

\section{Daftar Pustaka}

Azyumardi Azra, "Dalam Perspektif Timur: Wacana Akademis dan ilmiah Pengimbang Orientalisme", Gatra, 5 Agustus 2000.

Bryan Turner, Teori-teori Sosiologi Modernitas Postmodernitas, ter. Imam Baehaqi dan Ahmad Baidlowi (Yogyakarta: Pustaka Pelajar, 2000).

Ihsan Ali Fauzi, "Orientalisme di Mata Orientalis", Ulumul Qur'an, no. 2 (1992).

F. Budi Hardiman, Menuju Masyarakat Komunikatif (Yogyakarta, Kanisius, 1993).

Hasan Hanafi, Oksidentalisme: Sikeap Kita terhadap Tradisi Barat ter.

M. Najib Buchori (Jakarta: Paramidana, 2000).

Maryam Jamilah, Islam dan Orientalisme: Sebuah Kajian Analitik. (Jakarta: Raja Grafindo Persada, 1997). 
Maxime Rodinson, Mubammad (New York: Random House Inc., 2002).

Muhammad 'Âbid Al-Jâbirî, Takwîn al-Aql al-'Arabî (Beirut: Markâz Dirâsah al-Wihdah al-'Arabiyah, 1989). , Bunyatu al-'Aql al-'Arabî (Beirut: Markâz Dirâsah al-Wihdah al-'Arabiyah, 1990.

Kritik Kontemporer atas Filsafat Arab-Islam, ter. Moch Nur Ikhwan (Yogyakarta: Islamika, 2003).

Edward W. Said, Orientalisme, ter. Asep Hidayat (Bandung, Pustaka, 1985).

A. Muin Umar, Orientalisme dan Studi tentang Islam (Jakarta: Bulan Bintang, 1978).

William C. Placher, Unapologetic Theology (Loisville: Westminster/Jhon Knox, 1989). 